\title{
FAKTOR YANG BERPENGARUH TERHADAP KEBERHASILAN DALAM PEMBERIAN ASI EKSKLUSIF DI DESA HAMPARAN PERAK KEC. HAMPARAN PERAK KAB. DELI SERDANG
}

Keywords: Factors, Success, Exclusive Breastfeeding

\section{PENDAHULUAN}

Upaya peningkatan pemberian

Air Susu Ibu (ASI) berperan sangat besar terhadap pencapaian dua dari empat sasaran tersebut, yaitu menurunnya angka kematian bayi dan menurunnya prevalensi gizi kurang pada anak balita. World Health Organization/United Nations Children's Fund (WHO/UNICEF), pada tahun 2003 melaporkan bahwa 60\% kematian balita langsung maupun tidak langsung disebabkan oleh kurang gizi dan 2/3 dari kematian tersebut terkait dengan praktek pemberian makan yang kurang tepat pada bayi dan anak. Oleh karena itu penting sekali penerapan pola pemberian makan terbaik bagi bayi dan anak (Depkes RI, 2007. Hlm.1).

*) Desi Handayani Lubis, S.ST., M.Kes., Dosen STIKes Flora Medan 
Pada masa modern seperti saat ini sebagian ibu muda merasa enggan menyusui. Sebenarnya, budaya tersebut sudah membudaya sekian lama terutama di kota-kota besar. Semula itu dilakukan oleh para ibu muda di Eropa dan Amerika pada awal abad ke-20. Tindakan ini menyebabkan anak mudah terserang penyakit, karena daya tahan tubuhnya lemah (Prasetyono, 2009. Hal 11).

Ternyata, fenomena yang menunjukkan bahwa sebagian ibu muda tidak menyusui anaknya tidak hanya terjadi di negara-negara maju, tetapi juga di negara-negara berkembang, misalnya Indonesia. Promosi susu formula sangat mempengaruhi pemikiran para ibu yang kurang memiliki pengetahuan yang luas tentang ASI (Prasetyono, 2009. Hal 11).

\section{KAJIAN TEORITIS}

ASI merupakan suatu cairan hidup, yang berubah dan berespon terhadap kebutuhan bayi seiring dengan pertumbuhannya. ASI mengandung zat antiinfeksi penting yang membantu bayi melawan infeksi dan penyakit. ASI juga membuat respon instan terhadap infeksi dengan cara memproduksi satu set baru immunoglobulin ampuh yang mempercepat sistem imun bayi dengan cara membunuh bakteri dan virus (Pitaloka, 2008. Hal 11).

\section{ASI eksklusif adalah} pemberian ASI saja sejak bayi lahir sampai sekitar usia 6 bulan. Selama itu bayi tidak diharapkan mendapatkan tambahan cairan lain seperti susu formula, air jeruk, air teh, madu, air putih. Pemberian ASI secara benar dapat mencukupi kebutuhan bayi sampai usia 6 bulan, tanpa makanan pendamping (Sujiatini, Nurjanah, Kurniati, 2017. Hal 40).

Menyusui berarti memberikan ASI yang memang diperuntukkan bagi bayi. Susu lain yang biasa diberikan kepada bayi umumnya dibuat dari susu sapi atau kadang susu kambing atau kedelai, dan disebut susu formula.(Pitaloka, 2008. Hal 10).

Inisiasi Menyusu Dini (IMD) adalah perilaku pencarian puting payudara ibu sesaat setelah bayi lahir. Pada jam pertama, bayi berhasil 
menemukan payudara ibunya. Inilah awal hubungan menyusui antara bayi dan ibunya, yang akhirnya berkelanjutan dalam kehidupan ibu dan bayi (Prasetyono. 2009).

ASI diberikan kepada bayi karena mengandung banyak manfaat dan kelebihan. Diantaranya ialah menurunkan risiko terjadinya penyakit infeksi, misalnya infeksi saluran pencernaan (diare), infeksi saluran pernafasan, dan infeksi telinga. ASI juga bisa menurunkan dan mencegah terjadinya penyakit noninfeksi, seperti penyakit alergi, obesitas, kekurangan gizi, asma, dan eksem. Selain itu, ASI dapat pula meningkatkan IQ dan EQ anak (Prasetyono, 2009. Hal 27).

\section{Informasi tentang ASI perlu} diberikan kepada siapa saja dan sedini mungkin agar terjadi lingkungan yang mendukung pemberian ASI. Pemberian informasi untuk usia kanakkanak. Anak sekolah Taman Kanakkanak dan Sekolah Dasar diperkenalkan tentang pemberian ASI dengan cara memperlihatkan dan menjelaskan bahwa semua makhluk yang melahirkan akan menyusui bayinya sendiri. Dengan demikian mereka akan tahu bahwa bayi manusia sewajarnya juga mendapat ASI ibunya sebagaimana sapi menyusui anak sapi (Sidi, et al. 2004. Hal 2).

Setiap tenaga kesehatan yang memberikan pelayanan kesehatan ibu dan perawatan bayi baru lahir seharusnya mempunyai pedoman tertulis tentang menyusui, yang mencakup perawatan calon ibu, ibu yang baru melahirkan serta ibu yang menyusui. Pedoman ini hendaknya memperhatikan dan memasyarakatkan peraturan/perundangan yang mendukung program peningkatan penggunaan ASI. Para petugas perlu menyadari sepenuhnya pentingnya menyusui dan untuk ini harus dibekali pengetahuan tentang manfaat menyusui serta keterampilan penatalaksanaan laktasi agar dapat melaksanakan tugas penyuluhan dan tata laksana laktasi yang baik dan benar (Sidi, et al. 2004. Hal 3).

\section{METODE PENELITIAN}

Desain penelitian yang digunakan dalam penelitian ini adalah penelitian deskriptif analitik yakni 
suatu penelitian yang bertujuan untuk memberikan gambaran tentang realitas pada obyek yang diteliti secara obyektif (Suyanto, dan Salamah, 2009.

Hal. 34). Desain digunakan untuk mengidentifikasi faktor yang berpengaruh terhadap keberhasilan pemberian ASI eksklusif.

Penelitian ini dilakukan di Desa Hamparan Perak yang berada di wilayah kerja Puskesmas Hamparan Perak dilakukan September 2017 sampai dengan Juni tahun 2018, dengan pertimbangan bahwa di wilayah kerja Puskesmas Hamparan Perak ini didapat data ibu yang memberikan ASI eksklusif yang diambil dari data di Puskesmas Hamparan Perak.

Populasi dalam penelitian ini adalah ibu yang sedang memberikan ASI eksklusif di Desa Hamparan Perak yang berada di wilayah kerja Puskesmas Kec. Hamparan Perak. Desa Hamparan Perak dipilih karena pada data Puskesmas Hamparan Perak menunjukkan cakupan ibu menyusui lebih banyak berada di Desa Hamparan Perak. Data ibu yang menyusui didapat dari data Puskesmas Desa Hamparan
Perak. Dari data yang ada diperoleh sebanyak 26 orang ibu yang sedang memberikan ASI eksklusif menyusui secara eksklusif.

\section{HASIL DAN PEMBAHASAN}

Hasil dari uji statistik diperoleh data bahwa sebagian besar responden berusia 26 - 30 tahun sebanyak 10 orang (38.5 \%). Berdasarkan pendidikan sebagian besar responden pada pendidikan menengah (SMU/SMK) sebanyak 19 orang (73.1 $\%)$. Berdasarkan pekerjaan sebagian besar responden adalah wiraswasta sebanyak 20 orang (76.9 \%). Berdasarkan penghasilan mayoritas responden berpenghasilan $<1.000 .000$ sebanyak 22 orang ( $84.6 \%)$. Berdasarkan paritas mayoritas responden memiliki anak satu sebanyak 17 orang ( $65.4 \%$ ). Data yang disajikan dapat dilihat pada tabel 5.1 berikut ini.

Tabel 5.1: Distribusi Responden Berdasarkan Karakteristik Data Demografi Ibu yang sedang Menyusui di Desa Hamparan Perak Kec. Hamparan Perak Kab. Deli Serdang 


\begin{tabular}{|c|c|c|c|}
\hline Kar: & akteristik & & \\
\hline Frekuens & & Persen & ase \\
\hline & sia : & & \\
\hline & $20-25$ tahun & 9 & 34. \\
\hline & $26-30$ tahun & 1 & 6 \\
\hline & $31-35$ tahun & 0 & 38. \\
\hline- & $36-40$ tahun & 3 & 5 \\
\hline & & 4 & 11. \\
\hline & & & 5 \\
\hline & & & 15. \\
\hline & & & 4 \\
\hline & Total & 2 & 100 \\
\hline & & 6 & \\
\hline
\end{tabular}

Tingkat pendidikan

- SD / SMP

- SMA

415.

14

- Perguruan tinggi 973.

- Tidak sekolah 21

17.7

3.8

\begin{tabular}{ccc}
\hline Total & 2 & 100 \\
& 6 & \\
\hline
\end{tabular}

Pekerjaan

- Wiraswasta

276.

- PNS

09

- Karyawan

13.8

519.

\begin{tabular}{ccc}
\hline Total & 2 & 100 \\
& 6 & \\
\hline
\end{tabular}

\section{Penghasilaan}

$\begin{array}{ll}\text { - Tidak } & 27.7\end{array}$

berpenghasilan 284 .

- $<1.000 .000,0026$

$\begin{array}{lll}- & 1.000 .000- & 2\end{array}$

2.000 .000

- $>1.000 .000$

\begin{tabular}{ccc}
\hline Total & 2 & 100 \\
& 6 & \\
\hline Paritas & & \\
$-\quad 1$ & 1 & 65. \\
$-\quad 2$ & 7 & 4 \\
$-\quad>3$ & 5 & 19. \\
& 4 & 2 \\
& & 15. \\
& & 4 \\
\hline Total & 2 & 100 \\
& 6 & \\
\hline
\end{tabular}

Berdasarkan uji statistik hubungan pemberian informasi yang benar tentang ASI dan pemberian ASI eksklusif diperoleh nilai $\mathrm{r}=-0.192$ yang berarti hubungan antara variabel tersebut tidak berhubungan dan berlawanan, dan diperoleh nilai $\mathrm{P}=$ 0.347, maka dapat disimpulkan tidak 
ada pengaruh yang signifikan antara informasi yang benar tentang ASI dan pemberian ASI eksklusif. Dapat dilihat pada tabel 2.1 berikut ini.

Tabel 2.1. Hubungan Informasi yang Benar tentang ASI dan Pemberian ASI Eksklusif.

\begin{tabular}{llcc}
\hline No & \multicolumn{1}{c}{ Variabel } & \multicolumn{1}{c}{ r } & \multicolumn{1}{c}{ Nilai } \\
& & \multicolumn{1}{c}{ P } \\
\hline 1. & Hubungan & -0.192 & 0.347 \\
& informasi yang & & \\
& benar tentang & \\
& ASI dan \\
& pemberian ASI \\
& eksklusif.
\end{tabular}

Salah satu kendala mensukseskan program ASI eksklusif adalah meningkatnya tenaga kerja wanita, sedangkan cuti melahirkan hanya 12 minggu, itupun 4 minggu harus diambil sebelum melahirkan. Untuk menanggulangi ini perlu disiapkan hal seperti: cuti melahirkan diperpanjang menjadi paling kurang 4 bulan untuk ibu yang menyusui, dengan jaminan gaji penuh selama cuti dan pekerjaan masih tetap terbuka bila cuti selesai; selama cuti ibu hanya memberikan ASI, jangan memperkenalkan susu formula dengan alas an agar terbiasa karena akan ditinggal kerja; tempat kerja disiapkan menjadi "mother-friendly working place" dimana terdapat fasilitas untuk memerah dan menyimpan ASI; bila fasilitas mengizinkan disediakan tempat penitipan bayi (Sidi, et al. 2004. Hal 5).

\section{SIMPULAN}

Berdasarkan hasil penelitian maka dapat disimpulkan:

1. Berdasarkan karakteristik Usia, didapatkan bahwa rata-rata usia responden adalah ibu-ibu dengan usia 26-30 tahun yaitu sebanyak 10responden $(38,5 \%)$. Berdasarkan tingkat pendidikan, didapatkan bahwa rata-rata responden adalah ibuibu dengan pendidikan SMA yaitu sebanyak 19 responden (73.1\%). Berdasarkan pekerjaan responden, didapatkan bahwa rata-rata responden adalah ibu-ibu 
dengan pekerjaan wiraswasta yaitu sebanyak 20 responden $(76.9 \%)$.

Berdasarkan

penghasilan

responden,

didapatkan bahwa rata-rata responden adalah ibu-ibu dengan penghasilan $<\mathrm{Rp}$ 1000.000 yaitu sebanyak 22 responden $(84.6 \%)$, sedangkan berdasarkan paritas, didapatkan bahwa rata-rata responden adalah ibu-ibu dengan jumlah anak 1 yaitu sebanyak 17 responden $(65.4 \%)$.

2. Dari data diperoleh bahwa faktor tatalaksana di tempat bersalin yang mendukung ASI dan menyediakan fasilitas menyusui di tempat umum adalah faktor yang berpengaruh terhadap keberhasilan pemberian ASI eksklusif. Untuk faktor tatalaksana di tempat bersalin yang mendukung ASI diperoleh angka korelasi variabel tatalaksana di tempat bersalin yang mendukung ASI dan pemberian ASI eksklusif sebesar 0.458 yang berarti hubungan antara variabel tersebut mempunyai korelasi yang cukup. Korelasi kedua variabel bersifat signifikan karena angka signifikansi sebesar $0.019<0.05$, dan untuk faktor menyediakan fasilitas menyusui di tempat umum diperoleh angka korelasi variabel menyediakan fasilitas menyusui di tempat umum dan pemberian ASI eksklusif sebesar 0.394 yang berarti hubungan antara variabel tersebut mempunyai korelasi yang cukup. Korelasi kedua variabel bersifat signifikan karena angka signifikansi sebesar $0.047>0.05$.

\section{DAFTAR PUSTAKA}

Ashar, T., Lubis, Z., \& A, E. (2008). Analisis Pola Asuh Makan dan Status Gizi pada Bayi di Kelurahan PB Selayang

Medan. 2 Desember 2008, from Jurnal ASI.Pdf-Adobe Reader.

Bahiyatun. (2009). Buku Ajar Asuhan Kebidanan 
Nifas Normal. Jakarta :

EGC.

Hidayat,

A. A. (2007).

Metodologi penelitian

kebidanan teknik

analisis data. Jakarta:

Salemba medika

Manik, M., Sitohang, N. A., \&

Asiah, N. (2017).

Panduan penulisan

karya tulis ilmiah.

Medan: Tidak

dipublikasikan

Marja, T. T., Marita, R. N. P.,

Pekka, L. (1999).

Faktor-Faktor Yang

Berhubungan Dengan

Pemberian ASI Yang

Berhasil Pertama Kali

Oleh Ibu Ketika Anak

Berusia 3 Bulan.

Journal Of Advanced

Nursing, 29: 113-118.

DOI; 10.1046/j.1365-

2648.1999.00868.x

Murkoff, H., Eisenberg, A., \&

Hathaway, S., (2006).
Kehamilan: apa yang anda hadapi bulan per bulan,(ed 3). Jakarta: Arcan

Ningsih, W. A., (2009).

Perbandingan

Peningkatan

Pengetahuan Ibu

Tentang Pijat Bayi

Pada Balita Setelah

Mendapat Penyuluhan

dan Pemutaran VCD di

Kelurahan

Widodomartani,

Ngemplak,Sleman,

Yogyakarta. Desember

2009, from Ayu Widya

Ningsih_2009.pdf-

Adobe Reader.

Nursalam (2008). Konsep \& penerapan metodologi penelitian ilmu keperawatan. Jakarta: salemba medika 